\title{
Fate Coefficients for the Toxicity Assessment of Air Pollutants
}

\author{
Olivier Jolliet, Pierre Crettaz \\ Swiss Federal Institute of Technology, Institute of Soil and Water Management, CH-1015 Lausanne, Switzerland
}

Corresponding author: Pierre Crettaz

\begin{abstract}
The inclusion of fate and exposure is a central issuc in Life Cycle Impact Assessment (LCIA). According to the framework developed by the Society of Environmental Toxicity and Chemistry (SETAC), fate and exposure route are included through a fate coefficient which makes the link between an emission and the related increase in concentration.

In the Critical surface-time 95 methodology, fate factors of air pollutants are determined empirically at a world level as the ratio of measured concentration to the total cstimated cmission flow. Based on a detailed study performed for seventeen pollutants, a correlation is developed to predict fate factors from the residence time. Variation of a factor 10000 are observed for the fate coefficient. Empirical fate factors are compared to modelled fate factors and are found to have a similar order of magnitude.
\end{abstract}

Keywords: Air pollutants, fate coefficients; dilution, air pollutants; exposure, air pollutants; fate factors of air pollutants, empirical approach; LCIA; Life Cycle Impact Assessment; residence time, air pollutants; toxicity assessment, air pollutants

\section{Introduction}

Goal definition and inventory steps are relatively well defined for LCA. On the other hand, impact assessment clearly needs to be improved. The inclusion of fate and exposure in the characterisation of toxicity has been recognised as one of the major issues to be addressed (UDO DE HAEs et al., 1996; Jolliet et al., 1996).

A general framework for the characterisation step of human toxicity and ecotoxicity, including fate, has been provided by the SETAC working group on Life Cycle Impact Assessment (Jolliet et al., 1996). In this framework, the effect score $\left(S^{m}\right)$ of substances " $i$ " emitted in a media " $\mathrm{m}$ " is expressed as the product of an effect factor $(E)$ and of a fate $(F)$ factor:
$S^{m}=\sum_{i} F_{i}^{m} E_{i}^{m} M_{i}^{m}$

where:

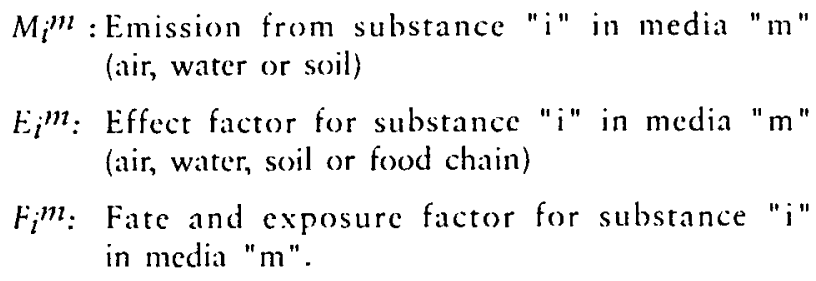
(air, water or soil)

$E_{i}{ }^{\prime \prime}$ : Effect factor for substance " $i$ " in media "m" (air, water, soil or food chain)

$F_{i}{ }^{m}$ : Fate and cxposure factor for substance " $\mathrm{i}$ in media " $\mathrm{m}$ ".

This can be casily generalised to inter-media transfer by considering that the emission in media " $\mathrm{m}$ " can also consist of a inter-media transfer from media " $n$ " to media m:

$$
\mathrm{M}_{i}^{n \rightarrow m}=\mathrm{f}_{i}^{\mathrm{n} \rightarrow \mathrm{m}} \mathrm{M}_{i}^{n}
$$

where:

$$
f_{i}^{m->n}
$$

is the fraction of the emission in media " $n$ " reaching media "m".

Most of the methods currently applied in LCIA do not consider the fate behaviour, i.e. they assume that all substances have the same fate properties. Approaches such as the critical volume (BUS, 1984) or the CML 1992 methods (HeIJungs et al., 1992) just compare the emission to a maximal critical concentration or to a No Effect Concentration. It therefore assumes that the fate factor is equal to unity for all substances. This is clearly not a valid assumption since the persistence of the pollutants can vary by a factor higher than 10000 . Other methodologies, such as the Danish EDIP method (Environmental Development of Industrial Products: HAUSCHILD, 1994), are limited to a partial fate analysis. 


\section{Methodological Principles for a Full Fate Analysis}

According to JolLift et al. (1996), an LCIA method can perform a full fate and exposure analysis if $F$ effectively relates the inventory emission to the chosen toxicity effect factor. For instance, if the toxicity reference is a tolerable daily intake, then the fate factor should relate the emission to the amount of pollutant effectively absorbed (e.g., in food). If a concentration limit is used as toxicity reference, then $F$ should relate the emission to the corresponding concentration increase.

For air emission, the effect factor is assumed to be equal to the inverse of the Predicted No Effect Concentration (PNEC):

$E_{i}=1 / P N E C$

In this case, to perform a full fate analysis, the fate factor should relatc the emission to the integration of the related mean concentration increase at ground level $\left(\overline{\delta C}_{i}\left|\mathrm{~kg} \mathrm{~m}^{-3}\right|\right)$ :

$F_{i}=\frac{\int_{0}^{\infty} \overline{\delta C}_{i}(t) d t}{M_{1} / A}$ where $\mathrm{A}$ is the ground area of the considered region $\left[\mathrm{m}^{2}\right]$. To understand the units of the fate coefficient $F i\left[\mathrm{~m}^{2} \mathrm{yr} \mathrm{m}^{-3}\right]$, a fate factor of $10^{-3}\left[\mathrm{~m}^{2} \mathrm{yr} \mathrm{m}^{-3}\right]$, for example, means that an emission flow of $1\left[\mathrm{~kg} \mathrm{yr}^{-1} \mathrm{~m}^{-2}\right]$ generates a concentration increase of $1\left[\mathrm{~g} / \mathrm{m}^{3}\right]$.

At steady-state, equation (3) is reduced to (JoLLIET, 1994; GUINÉE et al., 1996, p.41):

$F_{i}=\frac{\overline{\delta C i}}{\dot{M} i / A}$

where

$\dot{M} i / A$

is the emission flow per unit area $\left[\mathrm{kg} \mathrm{yr}^{-1} \mathrm{~m}^{-2}\right]$.

This corresponds to the "PFC/PNEC" approach (Predicted Environmental Concentration/Predicted No Effect Concentration, where $d C i=P E C$ ) commonly used in risk assessment.

JoLIFE and CRETTA (1996, appendix 1) also demonstrated that equation (2) and (3) imply that the characterisation factor is equal to the ratio of the absorbed dose divided by the acceptable dose:

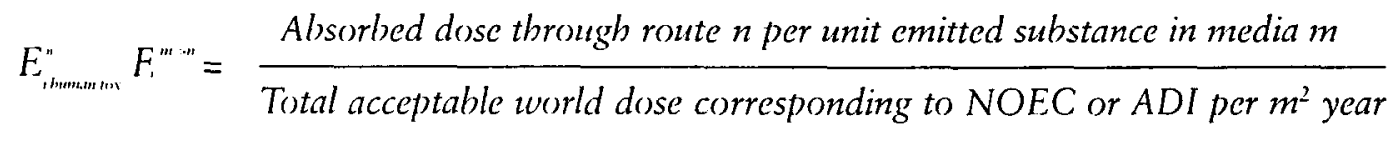

\section{Calculation of the Fate Coefficient}

\subsection{Existing methods}

In practise, the exposure and fate factor could be determined by different approaches:

1. Complex dynamic models

Complex dynamic models such as EMEP could be applied (TuOvinen et al., 1994). In addition to the question of the accuracy of such models, they cannot be applied on a global scale for a large number of substances; only a few substances have been modelled so far.

\section{Modelled approach based on USES}

GUINÉE et al. (1996) have recently calculated fate and effect factors for 100 substances using the USES model (Uniform System for the Evaluation of Substances). In USES, level III Mackay models are used to calculate the Predicted Environmental Concentration ( $\delta \mathrm{C} i=\mathrm{PEC}$ ) which is compared with the PNEC. On one hand, the advantage of the method is that it takes the inter-media transfer directly into account. On the other hand, the variation in the height of dilution is not considered. Moreover, USES requires the knowledge of a large number of parameters. This implies that default values are often used due to the lack of available data.
3. Empirical approach: Critical Surface-Time 94

According to Jolliet (1994), the fate factor can be calculated at steady state on the basis of mass conservation as:

$$
\mathrm{F}_{\mathrm{i}}=\tau_{\mathrm{i}} / \mathrm{V}_{\mathrm{i}}
$$

where

$\tau_{i}$ : residence-time characterising both degradation and deposition rates $[y r]$

$V_{i}$ : volume of dilution per unit surface, that is height of dilution $\left[\mathrm{m}^{3} \mathrm{~m}^{-2}\right.$ ]

This approach is quite suitable for water and soil pollutants, as their volumes of dilution and residence times can be directly calculated on the basis of available data from the literature. For emissions to air, the situation is more complex as it is mainly the concentration at the earth surface which has a direct toxicological impact. Moreover, the height of dilution varies from one substance to another. 
To solve this problem, JoLL.let (1994) suggested an approach to empirically determine the overall response of the environment according to equation (4): if measurements of the concentration and estimates of the cmission flow are available for a given area, the fate coefficient can be directly determined as the ratio of the mean measured concentration at earth level $\left(\overline{\delta C}_{i}\right)$ divided by the total emission flow per unit area $(\dot{\mathrm{M}} \mathrm{i} / \mathrm{A})$. The first empirical estimates of fate coefficients were calculated at a regional scale (Switzerland), showing important variation in the height of dilution of the different pollutants. An unsolved problem was that, at this scale, export and import can play a significant part due to the transport of pollutants across the regional borders. This problem of import-export is suppressed if the whole world is considered. Morcover, as emission listed in an LCA inventory can take place all over the world, specific Swiss coefficients are not relevant for most applications. The pertinence of the approach will be enhanced if the whole world is consid. ered. There is therefore a need to generalise this empirical approach at a global level.

\subsection{Fate factors according to Critical Surface-Timc 95: detailed study}

In the Critical Surface-Time 95 methodology (CST 95), fate factors and corresponding heights of dilution were determined at a global scale (world area of $5.1 \cdot 10^{14}$ $\mathrm{m}^{2}$ ) on the basis of estimated emissions and measured concentrations (CRI:ITA\% and Jou.til:T, 1996). Only emissions and effects in the air were considered. In addition, formation of decaly products, spatial information and inter-media transport were not taken into account.

In the first stage, a detailed study has been carried out for 17 substances for which emissions and concentrations were available at world level; these gases are: kcy greenhouse gases (nitrous oxide, carbon dioxide, methane, chlorofluorocarbons CFC-11 and CFC-12), eight hydrocarbons (ethane, ethene, propane, propene, $\mathrm{i}$-butane, $n$-butane, $\mathrm{i}$-pentane, n-pentane) and a few other trace gases (carbon monoxide, sulfur dioxide, nitrogen oxides, ozone, fine particles). Results for fate factors as well as heights of dilution are listed in Table 1 and plotted in Figure 1 as a function of pollutant residence-time (log-log scale).

Heights of dilution range from 30 to $22000\left[\mathrm{~m}^{3} \mathrm{~m}^{-2}\right]$. For short residence time gases, the increase of the height of dilution when the residence time increases in consistent with the principle "the longer the life-time, the higher the volume of dilution". For greenhouse gases, a threshold volume of dilution close to $10000\left[\mathrm{~m}^{3} \mathrm{~m}^{-2}\right]$ is reached. It is in accordance with the total atmospheric equivalent volume of $8000\left[\mathrm{~m}^{3} \mathrm{~m}^{-2}\right.$ ] calculated by CRETTAZ (CRETTAZ and JolLIET, 1996).
Table 1: Fatc factors and heights of dilution according to CRETTAZ and JOLLIFT (1996)

\begin{tabular}{|cccc|}
\hline Substance & $\begin{array}{c}\text { Residence- } \\
\text { time } \\
{[\mathrm{yr}]}\end{array}$ & $\begin{array}{c}\text { Fate factor } \\
{\left[\mathrm{m}^{2}-\mathrm{yr} / \mathrm{m}^{3}\right]}\end{array}$ & $\begin{array}{c}\text { Heights of } \\
\text { dilution } \\
{\left[\mathrm{m}^{3} / \mathrm{m}^{2}\right]}\end{array}$ \\
\hline $\mathrm{N}_{20}$ & 135 & $6.00 \mathrm{E}-03$ & 22000 \\
$\mathrm{CO}_{2}$ & 120 & $1.00 \mathrm{E}-02$ & 12000 \\
$\mathrm{CH}_{4}$ & 11 & $1.00 \mathrm{E}-03$ & 10400 \\
$\mathrm{CFC}-11$ & 74 & $1.90 \mathrm{E}-02$ & 3890 \\
$\mathrm{CFC}-12$ & 111 & $2.70 \mathrm{E}-02$ & 4100 \\
$\mathrm{CO}$ & 0.21 & $1.60 \mathrm{E}-05$ & 12253 \\
SO2 & 0.012 & $5.00 \mathrm{E}-06$ & 2370 \\
$\mathrm{NO}$ & 0.003 & $3.40 \mathrm{E}-06$ & 887 \\
Particles & 0.02 & $6.30 \mathrm{E}-06$ & 3210 \\
Ethane & 0.11 & $1.30 \mathrm{E}-04$ & 860 \\
Ethene & 0.004 & $1.00 \mathrm{E}-05$ & 390 \\
Propane & 0.029 & $1.10 \mathrm{E}-04$ & 273 \\
Propene & 0.0014 & $1.40 \mathrm{E}-06$ & 940 \\
i-butane & 0.023 & - & - \\
n-butane & 0.023 & $2.00 \mathrm{E}-04$ & 115 \\
i-pentane & 0.0082 & $1.60 \mathrm{E}-04$ & 53 \\
n-pentane & 0.0082 & $2.80 \mathrm{E}-04$ & 30 \\
VOC $\rightarrow$ O3 & - & $1.20 \mathrm{E}-04$ & - \\
\hline & & & \\
\hline
\end{tabular}

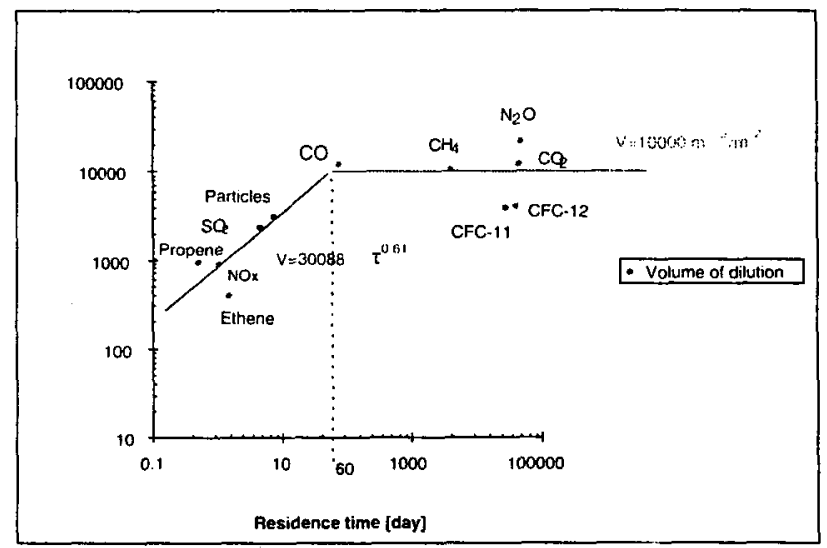

Fig. 1: Heights of dilution (volume per $\mathrm{m}^{2}$ ground area) as a function of residence-time. Regression analysis is indicated only for non-alkane pollutants

\subsection{Regression analysis and extrapolation method}

The above comments suggest that a correlation between heights of dilution and residence times can be investigated. To find out this relationship, a regression analysis is carried out for pollutants with a short residence time. If alkanes are excluded (due to uncertain data), $V$ is given as a function of the residence time (in years) as follows $(\rightarrow$ Fig. 1): 
$-V(\tau)=a \cdot \tau^{b}\left|m^{3}-m^{-2}\right|$ for $\tau<0.164$ year (60 days)

with the following adjusted coefficients and $95 \%$ confidence interval:

$a=30100,14000<a<64000 ; b=0.61 \pm 0.37 ;\left(R^{2}=0.82\right.$, 6 measurcments)

$-V=10000\left[\mathrm{~m}^{3}-\mathrm{m}^{-2}\right]$ for $\tau>0.164$ year

A quick evaluation of the fate and exposure behaviour of any substances can be performed on the basis of this extrapolation method. Results of an extrapolation for 91 substances are presented in the appendix. One must bear in mind that predicted fate factors are just a first order of magnitude ( \pm factor 2.1 on the a parameter). A specific study, involving estimations of global emissions and concentrations, is required for a more accurate determination of the fate factor.

\section{Comparison with Other Studies and with the Modelled Approach}

The whole earth surface, i.e. a global scale, is taken into account in this paper. Other scales, such as a regional (Switzerland) and continental scale (Europe), have been considered in previous studies (Jol.1.1F T, 1994), (TM.NBARI)ON, 1995). Results from these different studies are summarised in Table 2 .

The importance of import-export in regional estimation of global effects such as global warming leads to amazing results. The $\mathrm{CO}_{2}$ height of dilurion is much higher at a regional scale. This is due to the export of this substance from Switzerland towards oceans and developing countries, which increases the apparent volume of dilution. This indicates that it does not make sense to select a regional scale for greenhouse gases. On the other hand, pollutants with a short residence time such as $\mathrm{NO}_{\mathrm{X}}, \mathrm{CO}$, $\mathrm{SO}_{2}$ present similar heights of dilution at a regional and global scale. Therefore, a regional evaluation of the fate factor produces a reasonable approximation of the global factor for these pollutants. The difference in heights of dilution for particles is observed because only small particles were considered at a global scale, whereas no size distinction was carried out at a regional scale.

The comparison with the fate coefficient calculated by USES was carried out in two steps for $\mathrm{SO}_{2}$ and $\mathrm{NO}_{\mathrm{X}}$. In the first comparison performed in May 96 (GuINÉE et al., 1996 final draft), fate coefficients were much too high as calculated by USES. This led to a check of the model parameters, where some default values proved unsuitable for these pollutants. Final results published by GuINÉE et al. give fate factors of the same order of magnitude as the CST 95 empirical fate factors. We should point out that a main difference between the empirical and the modelling approach is that a fixed volume of dilution of $1000\left[\mathrm{~m}^{3} /\right.$ $\mathrm{m}^{2}$ ] is assumed by the model USES 1.0 (JAGER, 1994) while the volume of dilution significantly changes from one substance to another in the empirical approach.
Table 2: Comparison of the fate factor and height of dilution for different scales and for the USES model. (R) : Regional scale (Switzerland), (E): Continental scale (Europe), (G) : Global scalc (W'orld). (USES): fate factors calculated by GUINEE (GUINEE (ct al, 1996), using the risk assessment model USES

\begin{tabular}{|c|c|c|c|c|}
\hline Pollutants $R$ & $\begin{array}{c}\text { Residence- } \\
\text { time } \\
{[\mathrm{yr}]}\end{array}$ & $\begin{array}{c}\text { Height } \\
\text { of dilution } \\
{\left[\mathrm{m}^{3} / \mathrm{m}^{2}\right]}\end{array}$ & $\begin{array}{c}\text { Fate } \\
\text { factors } \\
{\left[\mathrm{m}^{2}-\mathrm{yr} / \mathrm{m}^{3}\right]}\end{array}$ & Reference \\
\hline $\mathrm{CO}_{2}(\mathrm{R})$ & 120 & 889860 & $1.30 \mathrm{E}-04$ & [JOLLIET, 1994] \\
\hline $\mathrm{CO}_{2}(\mathrm{G})$ & 120 & 12030 & $1.00 \mathrm{E}-02$ & [Present study] \\
\hline $\mathrm{CO}(\mathrm{R})$ & 0.21 & 11116 & $1.90 \mathrm{E}-05$ & [JOLLET, 1994] \\
\hline $\mathrm{CO}(\mathrm{G})$ & 0.21 & 12250 & $1.70 \mathrm{E}-05$ & [Present study] \\
\hline $\mathrm{SO}_{2}(\mathrm{R})$ & 0.012 & 3874 & $3.10 \mathrm{E}-06$ & [Jolliet, 1994] \\
\hline $\mathrm{SO}_{2}(\mathrm{C})$ & 0.012 & 4021 & $3.00 \mathrm{E}-06$ & [T \\
\hline $\mathrm{SO}_{2}(\mathrm{G})$ & 0.012 & 2372 & $5.10 \mathrm{E}-06$ & [Present study] \\
\hline $\mathrm{SO}_{2}$ (USES) & 0.0028 & 1000 & $2.80 \mathrm{E}-06$ & [GUINĖE et al, 1996] \\
\hline$N O_{X}(\mathrm{R})$ & 0.003 & 446 & $6.70 \mathrm{E}-06$ & [JOLLIET, 1994] \\
\hline$N O_{x}(C)$ & 0.003 & 692 & $4.00 \mathrm{E}-06$ & [TALABARDON, 1995] \\
\hline $\mathrm{NO}_{X}(\mathrm{G})$ & 0.003 & 889 & $3.40 \mathrm{E}-06$ & [Present study] \\
\hline$N O_{X}$ (USES) & 0.0027 & 1000 & $2.70 \mathrm{E}-06$ & [GuINÉE et al, 1996] \\
\hline Particles (R) & 0.03 & 397 & $8.00 \mathrm{E}-05$ & [JOLLIET, 1994] \\
\hline Particles (G) & i) 0.02 & 3168 & $6.00 E-06$ & [Present study] \\
\hline
\end{tabular}

\section{Conclusion}

This study reveals that it is possible to incorporate the fate behaviour of the substances within LCIA. The range of fate factors proves that the fate and exposure factor cannot be assumed to be 1 for all pollutants and must be included in LCIA. The strong variation in the height of dilution from one substance to another shows that the assumption of a permanent height of dilution is not valid and should not be considered in modelling. This paper also provides a first estimate of practical factors for about one hundred substances. This preliminary list could easily be extended to other toxic chemicals, implying the gathering of their residence time. This is worthwhile in comparison to the modelling approach for which data availability remains a point of attention. By combining these fate and exposure factors with toxicological values, new LCA characterisation factors could be deduced for human toxicity and compared with those of CML 1996 (GUINÉE et al., 1996).

Comparison between the impact of air emissions and that of water or soil emission, including the intrinsic toxicity, has also been performed and published for agricultural applications (AUDSLEY et al., 1996). 


\section{References}

Aussit: F. Ee al. (1996): Harmonization of life cycle assessment for agriculture. Final report of the European Concerted Action. Draft version June 1996, pp.53

BUS (1984): Ökobilanzen von Packstoffen. Schriftenreihe Umweltschutz $n^{\circ} 24$, Bundesamt für Umweltschutz, $\mathrm{CH}-3003$ Bern

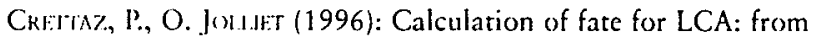
cmission to concentration. Swiss Fedcral Institute of Technology, Institute of Soil and Water Management, $\mathrm{CH}-1015$ Lausanne (submitted)

Dinkili, F, C.ı. Pohli, R. Mntjaz, B. Wal.dick (1996): Ökologische Bewertung mit der wirkungsorientierten Methode. Buwal $N^{\circ} x x$ (in press)

Guinie, J., R. Heimuncis, L. van Oers, D. van de Meent, T. Vermajar,, M. Rikkin (1996): LCA impact assessment of toxic releases. Ciencric modelling of fate, exposure, and effect on ecosystems and human beings with data for about 100 chemicals. RIVM report, pp. 90

Halsinin et al. (1993). The EDIP-method: Methods for screening and quantitative assessment of ecotoxicity in LCA of products. 2nd draft presented at the SETACISECOTOX workshop January $7-8,199.3$, l.inghy, DK. Haushild, M.Z., 1994. Characterizarion of product-specific toxicity in LCA, Integrating Impact Assessment into L.CA, Procedings of the 4th SETAC--Europe Congress, pp.75-81




Van DuIn, H.P. Golid): (1992): Envirommental Life Cycle Assessment of Products, Background and Guide. Centre of Environmental Science (CML), NL-2300) RA l.ciden

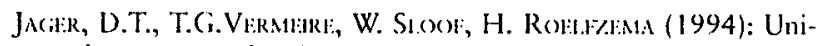
form system for the evaluation of substances effects assessments, $x x$

fontut, O. (1994): Critical Surface-Time: an evaluation method for life cycle assessment. In "Integrating Impact Assessment into LCA", Preceedings of the 4th SETAC-Europe Congress, pp. 133-142
Jotluft O., P. CretTaz (1996): Critical Surface-Time 95, a Life Cycle Impact Assessment methodology, including exposure and fate. Presented at the workshop of the EU concerted action on harmonization of Life Cycle Assessment in agriculture, Lyngby, DK, 15-19 January 1996. EPFL-HYDRAM, Paper 4/95, updated August 96

Jol.I.1FT, O. (1996) (ed.): Impact assessment of human and eco-toxicity in Life Cycle Assessment. With written contributions from J.Assies, M. Bovy, J.Guinée, G. Finnveden, M.Haushild, R.Heijungs, P. Hofstetter and J.Potting, SETAC Working subgroup on toxicity impact assessment in LCA. SETAC (in press)

TALABARDON M. (1995): Calcul de la durée de remanence et du volume de dilution des polluants atmospheriques. Travail de séminaire de génie rural, EPFL.

TeIOVININ, J., K. BakeTT, H. STYve (1994): Transboundary acidifying pollution in Europe. Calculated fields and budgets 1985-1993. EMEP/MSC-W Report 1/94, pp.70

UioO DE HAEs, H.A (1996) (ed.): The methodology of Life Cycle Impact Assessment. Report of the Europe working group on Life Cycle Impact Assessment, 5th draft. With written contributions from Bowy, Finnveden, G., Frischknecht, R., Giegrich, J., Guinće, J.B., Hauschild, M., Heijungs, R., Hofsterter, P., Jensen, A.A., Jollier, O., L.indcijer, F., Müller-Wenk, R., Nichols, Ph., Porting, J., Wenzel Christensen, H., White, P.

\section{Appendix}

This appendix presents the extrapolated fate factors and corresponding heights of dilution for about 100 pollutants. For this extrapolation, equations (7) and (8) have been applied. Residence times are taken from Dinkl:1. (1996). When only degradarion times are available, substances are listed in bold faced in Table 3. For these pollutants, the fate factor is a maximum value as the residence time could be lower than the degradation time due to deposition.

Table 3: Extrapolation of fate factors and the corresponding heights of dilution

\begin{tabular}{|c|c|c|c|c|c|}
\hline Nr. & Substance & $\begin{array}{c}\text { Residence- } \\
\text { time } \\
{[\mathrm{y} r]}\end{array}$ & $\begin{array}{c}\text { Residence- } \\
\text { time } \\
\text { [day] }\end{array}$ & $\begin{array}{l}\text { Fate factor } \\
\text { [m2-yr/m3] }\end{array}$ & $\begin{array}{c}\text { Height of } \\
\text { dilution } \\
\text { [m3/m2] }\end{array}$ \\
\hline 1 & Acetic acid & $3.96 \mathrm{E}-02$ & 14.5 & $9.42 E-06$ & 4202 \\
\hline 2 & Acetone & 1.37E-01 & 50.0 & $1.53 E-05$ & 8959 \\
\hline 3 & Acetoniltrile & $6.41 E-01$ & 234.1 & $6.41 E-05$ & 10000 \\
\hline 4 & Acrolein & $1.55 \mathrm{E}-03$ & 0.6 & 2.66E-06 & 582 \\
\hline 5 & Acrylonitrile & $6.62 \mathrm{E}-03$ & 2.4 & 4.69E-06 & 1411 \\
\hline 6 & Acrylic acid & $1.24 \mathrm{E}-03$ & 0.5 & $2.44 E-06$ & 508 \\
\hline 7 & Ammonia & $3.40 E-02$ & 12.4 & $8.88 E-06$ & 3829 \\
\hline 8 & Antimony & $3.00 \mathrm{E}-02$ & 11.0 & $8.46 E-06$ & 3547 \\
\hline 9 & Arsenic & $3.00 \mathrm{E}-02$ & 11.0 & $8.46 E-06$ & 3547 \\
\hline 10 & Benzene & $2.58 \mathrm{E}-02$ & 9.4 & 7.97E-06 & 3236 \\
\hline 11 & Benzoyl peroxide & $2.52 E-02$ & 9.2 & 7.90E-06 & 3189 \\
\hline
\end{tabular}




\begin{tabular}{|c|c|c|c|c|c|}
\hline Nr. & Substance & $\begin{array}{c}\text { Residence- } \\
\text { time } \\
\text { [yr] }\end{array}$ & $\begin{array}{c}\text { Residence- } \\
\text { time } \\
\text { [day] }\end{array}$ & $\begin{array}{l}\text { Fate factor } \\
{[\mathrm{m} 2-\mathrm{yr} / \mathrm{m} 3]}\end{array}$ & $\begin{array}{c}\text { Height of } \\
\text { dilution } \\
\text { [m3/m2] }\end{array}$ \\
\hline 12 & Benzyl chloride & $1.10 \mathrm{E}-02$ & 4.0 & $5.72 E-06$ & 1924 \\
\hline 13 & Bis-(Chloromethyl)ether & $9.68 \mathrm{E}-05$ & 0.04 & $9.03 E-07$ & 107 \\
\hline 14 & Bromomethane & 8.07E-01 & 294.8 & 8.07E-05 & 10000 \\
\hline 15 & 1,3-Butadiene & $3.78 E-04$ & 0.1 & $1.54 E-06$ & 246 \\
\hline 16 & 1-Butanol & $3.70 E-03$ & 1.4 & $3.74 E-06$ & 990 \\
\hline 17 & 2-Butanol & 4.93E-03 & 1.8 & 4.18E-06 & 1179 \\
\hline 18 & 2-Butanone & 2.73E-02 & 10.0 & $8.15 E-06$ & 3349 \\
\hline 19 & Butyl acrylate & $1.14 \mathrm{E}-03$ & 0.4 & 2.36E-06 & 483 \\
\hline 20 & Cadmium & $3.00 E-02$ & 11.0 & $8.46 \mathrm{E}-06$ & 3547 \\
\hline 21 & Carbon disulfide & 2.47E-02 & 9.0 & 7.83E-06 & 3148 \\
\hline 22 & Chlorine & 4.90E-02 & 17.9 & $1.02 E-05$ & 4785 \\
\hline 23 & Chlorobenzene & 4.80E-02 & 17.5 & $1.02 E-05$ & 4725 \\
\hline 24 & Chloroform & $2.20 \mathrm{E}-01$ & 80.4 & $2.20 E-05$ & 10000 \\
\hline 25 & Chloromethane & 7.30E-01 & 266.6 & 7.30E-05 & 10000 \\
\hline 26 & Chromium & $3.00 \mathrm{E}-02$ & 11.0 & $8.46 \mathrm{E}-06$ & 3547 \\
\hline 27 & Chloromethylether & $1.12 \mathrm{E}-02$ & 4.1 & 5.76E-06 & 1945 \\
\hline 28 & Cobalt & $3.00 \mathrm{E}-02$ & 11.0 & $8.46 \mathrm{E}-06$ & 3547 \\
\hline 29 & Copper & $3.00 \mathrm{E}-02$ & 11.0 & $8.46 \mathrm{E}-06$ & 3547 \\
\hline 30 & Cumene & 4.93E-03 & 1.8 & 4.18E-06 & 1179 \\
\hline 31 & 1,4-Dehydroxybenzene & $1.28 \mathrm{E}-03$ & 0.5 & 2.47E-06 & 518 \\
\hline 32 & Dibenzodioxin and furan & 1.10E-02 & 4.0 & $1.10 \mathrm{E}-06$ & 10000 \\
\hline 33 & Dibutyl phthalate & $3.66 \mathrm{E}-03$ & 1.3 & $3.72 E-06$ & 983 \\
\hline 34 & 1,2-Dichloroethane & 1.44E-01 & 52.6 & $1.56 \mathrm{E}-05$ & 9236 \\
\hline 35 & Dichloromethane & $3.20 \mathrm{E}-01$ & 116.9 & $3.20 \mathrm{E}-05$ & 10000 \\
\hline 36 & Dichloropropane & $3.21 E-02$ & 11.7 & 8.68E-06 & 3697 \\
\hline 37 & Diethanol amine & $3.56 \mathrm{E}-04$ & 0.1 & $1.50 \mathrm{E}-06$ & 237 \\
\hline 38 & Dimethyl amine & 4.57E-04 & 0.2 & 1.65E-06 & 276 \\
\hline 39 & Dimethyl phthalate & 5.53E-02 & 20.2 & $1.07 E-05$ & 5151 \\
\hline 40 & 1,4-Dioxane & 4.00E-03 & 1.5 & 3.85E-06 & 1038 \\
\hline 41 & Epichlorohydrin & $7.20 \mathrm{E}-02$ & 26.3 & 1.19E-05 & 6051 \\
\hline 42 & Ethyl acrylate & 1.17E-03 & 0.4 & 2.39E-06 & 490 \\
\hline 43 & Ethyl benzene & 4.38E-03 & 1.6 & $3.99 E-06$ & 1097 \\
\hline 44 & Ethylene glycol & 4.10E-03 & 1.5 & 3.89E-06 & 1054 \\
\hline 45 & Formaldehyde & $3.30 E-03$ & 1.2 & $3.58 \mathrm{E}-06$ & 923 \\
\hline 46 & $\mathrm{n}$-Hexane & 5.63E-03 & 2.1 & 4.40E-06 & 1278 \\
\hline 47 & Hexyl 2-ethyl acrylate & $1.20 \mathrm{E}-03$ & 0.4 & 2.41E-06 & 498 \\
\hline 48 & Hydrazine & $5.14 E-04$ & 0.2 & 1.73E-06 & 297 \\
\hline 49 & Hydrochloric acid & $1.20 \mathrm{E}-02$ & 4.4 & $5.92 E-06$ & 2028 \\
\hline 50 & Isobutyraldehyde & $1.21 E-03$ & 0.4 & $2.42 E-06$ & 500 \\
\hline
\end{tabular}




\begin{tabular}{|c|c|c|c|c|c|}
\hline Nr. & Substance & $\begin{array}{c}\text { Residence- } \\
\text { time } \\
{[y r]}\end{array}$ & $\begin{array}{c}\text { Residence- } \\
\text { time } \\
\text { [day] }\end{array}$ & $\begin{array}{l}\text { Fate factor } \\
\text { [m2-yr/m3] }\end{array}$ & $\begin{array}{l}\text { Height of } \\
\text { dilution } \\
{[\mathrm{m} 3 / \mathrm{m} 2]}\end{array}$ \\
\hline 51 & Isophorone & $2.00 \mathrm{E}-04$ & 0.1 & $1.20 \mathrm{E}-06$ & 167 \\
\hline 52 & Lead & $3.00 \mathrm{E}-02$ & 11.0 & $8.46 \mathrm{E}-06$ & 3547 \\
\hline 53 & Manganese & $3.00 \mathrm{E}-02$ & 11.0 & $8.46 \mathrm{E}-06$ & 3547 \\
\hline 54 & Methanol & $2.90 \mathrm{E}-02$ & 10.6 & 8.35E-06 & 3475 \\
\hline 55 & Methylacrylate & $1.33 E-03$ & 0.5 & $2.51 \mathrm{E}-06$ & 530 \\
\hline 56 & 2-Methyl-2-propanol & $2.83 E-03$ & 1.0 & 3.37E-06 & 840 \\
\hline 57 & 4-Methyl-2-pentanone & 2.27E-03 & 0.8 & 3.09E-06 & 735 \\
\hline 58 & Methyl isocyanate & $9.20 \mathrm{E}-04$ & 0.3 & 2.17E-06 & 423 \\
\hline 59 & Methyl methacrylate & $5.43 E-04$ & 0.2 & $1.77 \mathrm{E}-06$ & 307 \\
\hline 60 & Mercury & $3.00 E-02$ & 11.0 & 8.46E-06 & 3547 \\
\hline 61 & Naphthalene & 1.35E-03 & 0.5 & 2.52E-06 & 535 \\
\hline 62 & Nickel & $3.00 \mathrm{E}-02$ & 11.0 & $8.46 \mathrm{E}-06$ & 3547 \\
\hline 63 & Nitric acid & 9.00E-03 & 3.3 & 5.29E-06 & 1702 \\
\hline 64 & NMVOC & $8.00 E-03$ & 2.9 & 5.05E-06 & 1584 \\
\hline 65 & Pentachiorophenol & $6.88 \mathrm{E}-02$ & 25.1 & 1.17E-05 & 5886 \\
\hline 66 & Phenol & $7.83 E-04$ & 0.3 & 2.04E-06 & 384 \\
\hline 67 & Phosgene & $1.20 \mathrm{E}-02$ & 4.4 & $1.20 \mathrm{E}-06$ & 10000 \\
\hline 68 & Phthalic acid anhydride & $1.20 E-02$ & 4.4 & $1.20 \mathrm{E}-06$ & 10000 \\
\hline 69 & 2-Propanol & 5.91E-03 & 2.2 & 4.49E-06 & 1317 \\
\hline 70 & Propene & $8.18 E-04$ & 0.3 & 2.08E-06 & 394 \\
\hline 71 & Sodium hydroxide & $3.00 E-02$ & 11.0 & $8.46 E-06$ & 3547 \\
\hline 72 & Sodium sulphate & $3.00 \mathrm{E}-02$ & 11.0 & $8.46 \mathrm{E}-06$ & 3547 \\
\hline 73 & Suspended dust & $3.00 E-02$ & 11.0 & $8.46 \mathrm{E}-06$ & 3547 \\
\hline 74 & Styrene & 2.85E-04 & 0.1 & $1.38 E-06$ & 207 \\
\hline 75 & 1,1,2,2-Tetrachloroethane & 1.05E-01 & 38.4 & $1.38 E-05$ & 7617 \\
\hline 76 & Tetrachloroethene & 1.92E-01 & 70.1 & $1.92 E-05$ & 10000 \\
\hline 77 & Tetrachloromethane & $3.40 \mathrm{E}+01$ & 12418.5 & $3.40 \mathrm{E}-03$ & 10000 \\
\hline 78 & Titanium dioxide & $3.00 \mathrm{E}-02$ & 11.0 & $8.46 \mathrm{E}-06$ & 3547 \\
\hline 79 & Toluene & $5.30 \mathrm{E}-03$ & 1.9 & 4.30E-06 & 1232 \\
\hline 80 & $1,1,1$-Trichloroethane & $3.40 E+\infty 0$ & 1241.9 & $3.40 E-04$ & 10000 \\
\hline 81 & 1,1,2-Trichloroethane & $1.00 E-01$ & 36.5 & 1.35E-05 & 7394 \\
\hline 82 & Trichloroethene & $1.32 E-02$ & 4.8 & $6.14 \mathrm{E}-06$ & 2150 \\
\hline 83 & Vanadium pentoxide & $3.00 \mathrm{E}-02$ & 11.0 & 8.46E-06 & 3547 \\
\hline 84 & Vinyl chloride & 4.79E-03 & 1.7 & 4.13E-06 & 1158 \\
\hline 85 & Xylene & $1.95 \mathrm{E}-03$ & 0.7 & $2.91 E-06$ & 670 \\
\hline 86 & m-Xylene & $1.34 \mathrm{E}-03$ & 0.5 & $2.52 \mathrm{E}-06$ & 533 \\
\hline 87 & o-Xylene & $2.30 \mathrm{E}-03$ & 0.8 & $3.11 E-06$ & 740 \\
\hline 88 & p-Xylene & $2.20 \mathrm{E}-03$ & 0.8 & $3.05 E-06$ & 721 \\
\hline 89 & Zinc acetate & $3.00 \mathrm{E}-02$ & 11.0 & $8.46 \mathrm{E}-06$ & 3547 \\
\hline 90 & Zinc oxide & $3.00 E-02$ & 11.0 & $8.46 \mathrm{E}-06$ & 3547 \\
\hline 91 & Zinc sulfate & $3.00 \mathrm{E}-02$ & 11.0 & $8.46 E-06$ & 3547 \\
\hline
\end{tabular}

